\title{
Kompetensi Pengembangan Kewirausahaan Program Pos Pemberdayaan Keluarga (Posdaya) Pasir Mulya Kecamatan Bogor Barat Kota Bogor
}

\section{Competency in Entrepreneurial Development Programs of the Post Family Empowerment (Posdaya) in Bogor Subdistrict Neighborhoods West Pasir Mulya}

\author{
Atria Widyana ${ }^{1}$, Richard W.E. Lumintang ${ }^{1}$ \\ ${ }^{1}$ Departemen Sains Komunikasi dan Pengembangan Masyarakat, \\ Fakultas Ekologi Manuasia-IPB
}

\begin{abstract}
Unit family empowerment (Posdaya) is a locus for developing the welfare of families in increasing their income so that people can improve the quality of life. One of the forms in increasing their income by developing entrepreneurship. The activities of its members through Posdaya supported to detail useful skills and knowledge to develop their entrepreneurial endeavors. The purpose of this research is to recoquize the characteristics of the RWO2 as a member of the Posdaya Bina Sejahtera. In addition, analyses the development of entrepreneurship as well as the competencies contained in the activities Village of Posdaya Bina SejahteraBogor Subdistrict Neighborhoods West Pasir MulyaPasir Mulya. The research was carried out by quantitative and qualitative methods using questionnaires and in-depth interview. This research result indicates in the members of posdaya more women in category, productive the end of the age the majority last finished elementary school education and have a job entrepreneurship. The development of entrepreneurship in Posdaya Bina Sejahtera done with through training and assistance. The training and assistance produce competence the development of entrepreneurship in terms of knowledge and skills in the life of a day.
\end{abstract}

Keywords: Posdaya, entrepreneurship, competence

\section{Abstrak}

Pos Pemberdayaan Keluarga (Posdaya) adalah salah satu wadah untuk mengembangkan kesejahteraan keluarga dalam meningkatkan pendapatan sehingga masyarakat dapat meningkatkan kualitas hidup. Salah satu bentuk dalam meningkatkan pendapatan yaitu dengan mengembangkan kewirausahaan. Posdaya melalui kegiatannya membantu anggotanya untuk menggali keterampilan serta pengetahuan yang bermanfaat untuk mengembangkan kewirausahaannya. Tujuan dari penelitian ini adalah mengetahui karakteristik dari warga RW 02 sebagai anggota Posdaya Bina Sejahtera. Selain itu, menganalisis pengembangan kewirausahaan serta kompetensi yang terdapat dalam kegiatan Posdaya Bina Sejahtera Kelurahan Pasir Mulya Bogor. Penelitian ini dilakukan dengan metode kuantitatif dan kualitatif menggunakan kuesioner serta wawancara mendalam. Hasil ini menunjukkan dalam anggota Posdaya lebih banyak perempuan dengan golongan umur produktif penelitian akhir, mayoritas pendidikan terakhir tamat SD dan memiliki pekerjaan berwirausaha. Pengembangan kewirausahaan di Posdaya Bina Sejahtera dilakukan dengan melalui pelatihan dan pendampingan. Kegiatan pelatihan dan pendampingan menghasilkan kompetensi pengembangan kewirausahaan dalam segi pengetahuan dan keterampilan dalam kehidupan sehari-hari.

Kata kunci: Posdaya, kewirausahaan, kompetensi

\section{Pendahuluan}

Sumber daya manusia (SDM) merupakan modal yang sangat penting dalam melakukan pemberdayaan masyarakat. Dampak pemberdayaan masyarakat adalah muncul kemandirian masyarakat dalam mengatasi permasalahan yang terjadi melalui prakarsa dan kreatifitas untuk meningkatkan kualitas hidup. Indonesia pada September tahun 2000 ikut menandatangani Deklarasi Milenium pada Konfrensi Tingkat Tinggi (KTT) Perserikatan Bangsa-Bangsa (PBB). Deklarasi ini menyepakati tujuan-tujuan pembangunan global yang tertuang dalam tujuan pembangunan milenium (Millenium Development Goals - MDGs).

Tujuan utama pembangunan milenium (Millenium Development Goals) di Indonesia memprioritaskan pada pengentasan kemiskinan. Pada tahun 2013 jumlah penduduk miskin (penduduk dengan pengeluaran per kapita per bulan di bawah Garis Kemiskinan) di Indonesia mencapai 28,07 juta orang atau sebanyak 11,37\%. Menurut data BPS (2013), jumlah penduduk miskin di daerah perkotaan mencapai 10,33 juta orang atau sebanyak 8,39\%, sementara di daerah perdesaan 17,74 juta orang atau sebanyak $14,32 \%$. 
Menurut Suyono dan Haryanto (2009), pilihan utama untuk meningkatkan MDGs dan Human Development Index (HDI) adalah program kesehatan, pendidikan dan ekonomi. Indikator pembangunan kesehatan adalah bertambahnya usia harapan hidup, indikator program pendidikan adalah tingkat partisipasi anak usia sekolah dan bebas buta aksara, cakupan semua anak usia sekolah, dan rata-rata lamanya anak bersekolah, sedangkan indikator program ekonomi adalah peningkatan tingkat pendapatan masyarakat.

Menurut Pudji (2011), Pos Pemberdayaan Keluarga (Posdaya) adalah salah satu wadah untuk mengembangkan kesejahteraan keluarga dalam meningkatkan pendapatan sehingga masyarakat dapat meningkatkan kualitas hidup. Pos Pemberdayaan Keluarga (Posdaya) adalahsebuah gagasan baru membangun SDM dengan ciri khas "bottom up program",yang mengusung kemandirian, dan pemanfaatan sumber daya serta potensi lokal sebagai solusi.

Menurut Suyono dan Haryanto (2009), Posdaya sebagai sebuah gagasan pemberdayaan dari, oleh, dan untuk masyarakat adalah sebuah kegiatan pemberdayaan bagi warga masyarakat yang mengimplementasikan nilai-nilai kegotongroyongan di masyarakat. Posdaya merupakan forum silaturahmi, komunikasi, edukasi dan sebagai wadah koordinasi kegiatan penguatan fungsi keluarga secara terpadu. Penguatan fungsi-fungsi utama tersebut diharapkan memungkinkan setiap keluarga dapat semakin mampu membangun dirinya menjadi keluarga sejahtera, mandiri dan sanggup menghadapi tantangan masadepan dengan lebih baik. Program Posdaya diprioritaskan pada bidang ekonomi yaitu kewirausahaan. Salah satu upaya Posdaya dalam bidang ekonomi, membimbing masyarakat dalam menggali kreatifitas masyarakat salah satunya adalah berwirausaha. Kewirausahaan merupakan proses mengidentifikasi, mengembangkan, dan membawa visi ke dalam kehidupan. Visi tersebut bisa berupa ide inovatif, peluang, cara yang lebih baik dalam menjalankan sesuatu. Hasil akhir dari proses tersebut adalah penciptaan usaha baru yang dibentuk pada kondisi risiko atau ketidakpastian.

Pelatihan-pelatihan yang diberikan Posdaya mencakup, proses kreatif yang berlangsung selama kegiatan, serta pemberian dorongan dan motivasidari seluruh anggota keluarga ataupun aparat desa menjadikan ibu-ibu rumah tangga sebagai salah satu penggerak pemberdayaan masyarakat sehingga manfaat yang diberikan dalam kegiatan kemudian dapat disalurkan dalam meningkatkan kualitas hidup keluarga. Kemandirian pengetahuan yang ditunjukkan melalui kegiatan Posdaya juga dapat mendorongdan menjadi keteladanan bagi anggota keluarga lainnya untuk meningkatkan kualitas diri,dan pada akhirnya tercapai peningkatan kualitas sumber daya manusia secara keseluruhan. Penelitian ini bertujuan untukmenganalisis karakteristik responden sebagai anggota kelompok Posdaya dalam menunjang pengembangan kewirausahaan Program Posdaya dan pengembangan kewirausahaan membentuk kompetensi anggota kelompok Posdaya.

\section{Metode Penelitian}

Penelitian menjelaskan tentang mengembangan kewirausahaan kompetensi program Posdaya. Selain itu,menganalisis pengaruh yang terkait dengan variabelvariabel penelitian.Unit analisa dalam penelitian ini adalah anggota kelompok Posdaya Bina Sejahtera. Metode yang digunakan adalah pendekatan kuantitaif dan pendekatan kualitatif.

Pendekatan penelitian kuantitatif dilakukan menggunakan metode survai yaitu penelitian yang mengambil sampel dari suatu populasi dan menggunakan kuesioner sebagai alat pengumpul data yang pokok (Singarimbun dan Effendy, 1989). Pendekatan kualitatif digunakan untuk mendapatkan pemahaman yang mendalam tentang program Posdaya. Pendekatan kuantitatif ini dilakukan secara sinergis dengan pendekatan kualitatif agar diperoleh data yang komprehensif tentang objek yang diteliti. Data yang digunakan dalam penelitian ini adalah data primer dan data sekunder. Data primer diperoleh melalui wawancara dengan anggota kelompok Posdaya melalui pengisian kuisioner, sedangkan data sekunder diperoleh melalui buku, Penelitian terdahulu dan literatur yang terkait.

Subyek penelitian ini terdiri dari informan dan responden. Informan merupakan pihak-pihak yang memberikan keterangan tentang Program Posdaya, sedangkan responden merupakan pihak yang memberikan keterangan tentang diri dan kegiatan yang dilaksanakannya.Informan dalam penelitian ini adalah pendamping Posdaya Bina Sejahtera dan pengurus Posdaya Bina Sejahtera serta tokoh-tokoh yang terlibat dalam Posdaya. Populasi dalam penelitian ini adalah 4.766 jiwa 
yang merupakan penduduk Kelurahan Pasir Mulya. Populasi sasaran dalam penelitian ini 843 jiwa yang merupakan penduduk RW 02. Semua penduduk RW 02 merupakan anggota Posdaya Bina Sejahtera. Responden dalam penelitian ini adalah anggota kelompok dalam Posdaya.Responden terdiri dari 30 orang yang dipilih secara sengaja (purposive sampling).

Data yang diperoleh lalu dianalisis secara deskriptif, untuk menggambarkan situasi Posdaya serta peran Posdaya untuk masyarakat RW 02. Data kuantitatif diperoleh dari kuesioner yang diolah dengan menggunakan tabulasi silang. Pengolahan data kuantitatif dalam penelitian ini mengacu pada langkah-langkah pengolahan data dari Effendi (1989). Pertama, memasukkan data kuesioner ke dalam berkas data ke Microsoft Exce/2010. Kedua, membuattabel silang (crosstab). Ketiga, mengoreksi kesalahan-kesalahan yang ditemui setelah membaca tabel frekuensi atau tabel silang. Data hasil kuesioner terhadap responden akan diolah secara statistik deskriptif dengan menggunakan software SPSS for windows versi MB.

\section{Hasil dan Pembahasan}

Anggota kelompok Posdaya Bina Sejahtera adalah warga RW 02 Kelurahan Pasir Mulya. Setiap anggota kelompok Posdaya Bina Sejahtera terdapat karakteristik dari setiap anggota.

Pada golongan umur merupakan keadaan individu yang dihitung sejak lahir sampai pada saat umur pada tahun 2013 yaitu pada saat melakukan melakukan penelitianini.AnggotakelompokPosdayaBinaSejahtera memiliki golongan umur yang bervariasi. Penelitian ini lebih dominan pada golongan umur produktif akhir (49-64 tahun). Hal ini dikarenakan pola pemikiran pada umur produktif akhir lebih matang dalam hal berfikir, lebih banyak pengalaman akan kehidupan sehingga pola pemikiran untuk mengikuti kegiatan Posdaya akan merubah keluarga mereka menjadi lebih baik.

Pekerjaan adalah suatu profesi yang digeluti dalam kehidupan sehari-hari. Hasil penelitian, dapat terlihat bahwa sebagian besar anggota kelompok Posdaya Bina Sejahtera memiliki jenis pekerjaan berwirausaha. Namun sebagian besar berwirausaha dengan membuka warung sembako. Hanya terdapat beberapa orang yang berwirausaha dengan membuka pabrik sepatu, berjualan pupuk, rongsokan dan berjualan domba.

Pada perempuan pada umumnyayang memiliki pekerjaan berwirausaha dijalani yaitu dengan berjualan gorengan, es mambo, baju, nasi padang, nasi uduk dan alat-alat kosmetik. Namun terdapat beberapa yang memiliki pekerja non wirausaha yaitu sebanyak $6,7 \%$. Anggota Posdaya yang pekerjaannya non wirausaha seperti guru PAUD dan ibu rumah tangga. Keterlibatan anggota Posdaya yang non wirausaha yaitu sebagai Kader Posdaya. Pendidikan terakhir anggota Posdaya adalah sebagaian besar berpendidikan tamat SD. Berdasarkan hasil penelitian ini, menunjukkan tingkat pendidikan yang masih rendah, Presentase tingkat pendidikan tamat SD sebanyak $93,3 \%$. Hal ini yang merupakan dasar pentingnya Posdaya sehingga dapat membantu keluarga menjadi berkualitas dengan keterbatasan pendidikan yang masih rendah.

\section{Tingkat Pelatihan}

Tingkat pelatihan diukur untuk mengetahui partisipasi warga RW 02 sebagai anggota Posdaya Bina Sejahtera dalam mengikuti pelatihan yang diadakan oleh Posdaya Bina Sejahtera. Kegiatan pelatihan banyaknya yang hadir berdasarkan tingkat pekerjaan adalah anggota yang bekerja berwirausaha dengan persentase $78,6 \%$. Hal ini dikarenakan anggota yang bekerja sebagai wirausaha memiliki waktu lebih luang jika dibandingkan dengan yang bekerja dikantoran atau yang berpatokan dengan jam kerja. Namun terdapat sebagian anggota yang memiliki pekerjaan berwirausaha tidak dapat sering mengikuti pelatihan yaitu sebesar 21,4\%, kegiatan berjualan yang dilakukan tidak bisa ditinggalkan sehingga memaksakan tidak mengikuti pelatihan.

Kegiatan pelatihan tidak hanya dihadiri oleh anggota Posdaya yang memiliki pekerjaan sebagai wirausaha namun anggota Posdaya mengikuti kegiatan pelatihan karena faktor pendidikan yang rendah.Pendidikan terakhir anggota Posdaya tamat SD yang sering mengikuti pelatihan. Hal ini terlihat dari persentase anggota yang hadir mengikuti pelatihan dengan pendidikan terakhir tamat SD sebanyak 78,6\%. Berdasarkan jumlah responden yang menjadi anggota Posdaya yang berpendidikan tamat SMP hanya 2 orang yang kontribusinya dalam Posdaya adalah sebagai kader. Pengukuran diatas dapat disimpulkan bahwa intensitas dalam mengikuti pelatihan berpengaruh terhadap jenis 
Tabel 1 Karakteristik Responden Sebagai Anggota Posdaya Bina Sejahtera, Kelurahan Pasir Mulya, 2013

\begin{tabular}{lrr}
\hline \multicolumn{1}{c}{ Item } & Jumlah & Persentase \\
\hline Jenis Kelamin & & \\
Laki- laki & 9 & 30,0 \\
Perempuan & 21 & 70,0 \\
Total & 30 & 100,0 \\
Golongan Umur & & \\
Produktif pertengahan & 8 & 26,7 \\
Produktif akhir & 22 & 73,3 \\
Total & 30 & 100,0 \\
Pekerjaan & & \\
Wirausaha & 28 & 93,3 \\
Non Wirausaha & 2 & 6,7 \\
Total & 30 & 100,0 \\
Pendidikan & & \\
SD & 28 & 63,3 \\
SMP & 30 & 100,0 \\
Total & & \\
\hline
\end{tabular}

pekerjaan maupun tingkat pendidikan. Banyaknya anggota Posdaya yang mengikuti pelatihan adalah anggota yang bekerja berwirausaha dan pendidikan terakhir tamat SD.

\section{Tingkat Pendampingan}

Pendampingan merupakan forum diskusi atau wadah untuk bertukar pengalaman yang menjadikan gambaran serta pengetahuan yang bermanfaat untuk kedepannya. Penelitian ini, adanya pendampingan yang dilakukan oleh fasilitator untuk memberikan keterampilan sehingga dengan keterampilan tersebut dapat memberikan peluang untuk menciptakan inovasi lain untuk dapat menambah pendapatan keluarga serta dapat membuka lapangan kerja untuk orang lain.
Hasil penelitian ini dapat dilihat tingkat partsipasi warga RW 02 sebagaianggota Posdaya Bina Sejahtera dalam mengikuti kegiatan pendampingan yang dilakukan oleh Posdaya Bina Sejahtera. Hasil untuk mengetahui tingkat pendampingan responden yang merupakan warga RW 02 Kelurahan Pasir Mulya sebagai anggota Posdaya Bina Sejahtera yang berpengaruh terhadap jenis pekerjaan serta tingkat pendidikan terakhir anggota Posdya Bina Sejahtera sebagai responden.

Berdasarkan tabel tersebut terlihat bahwa tingkat partisipasi warga RW 02 dalam mengikuti pendampingan sangat tinggi. Hal ini terlihat lebih banyak anggota yang bekerja berwirausaha yang mengikuti pendampingan sebanyak $75 \%$. Hal ini dikarenakan keingintahuan warga dalam kegiatan pendampingan sangat tinggi. Kegiatan pendampingan

Tabel 2 Responden Berdasarkan Tingkat Pekerjaan Berpengaruh pada Kegiatan Pelatihan, Posdaya Bina Sejahtera, Kelurahan Pasir Mulya, 2013

\begin{tabular}{llcccrcr}
\hline \multirow{2}{*}{ Pelatihan } & \multicolumn{3}{c}{ Pekerjaan } & \multicolumn{2}{c}{ Total } \\
& \multicolumn{2}{c}{ Wirausaha } & \multicolumn{2}{c}{ Non Wirausaha } & & & \\
& & Jumlah & Persentase & Jumlah & Persentase & Jumlah & Persentase \\
\hline \multirow{2}{*}{ Total } & Sering & 22 & 78,6 & 2 & 100,0 & 24 & 80,0 \\
& Tidak Sering & 6 & 21,4 & 0 & 0,0 & 6 & 20,0 \\
& & 28 & 100 & 2 & 100,0 & 30 & 100,0 \\
\hline
\end{tabular}


Tabel 3 Jumlah dan Persentase Responden Berdasarkan Tingkat Pendidikan Berpengaruh pada Kegiatan Pelatihan, Posdaya Bina Sejahtera, Kelurahan Pasir Mulya, 2013

\begin{tabular}{llcccccc}
\hline \multirow{2}{*}{ Pelatihan } & \multicolumn{4}{c}{ SD } & \multicolumn{4}{c}{ Pendidikan } \\
& & & \multicolumn{2}{c}{ SMP } & \multicolumn{2}{c}{ Total } \\
& & Jumlah & Persentase & Jumlah & Persentase & Jumlah & Persentase \\
\hline \multirow{3}{*}{ Total } & Sering & 22 & 78,6 & 2 & 100,0 & 24 & 80,0 \\
& Tidak Sering & 6 & 21,4 & 0 & 0,0 & 6 & 2,0 \\
\hline & 28 & 100,0 & 2 & 100,0 & 30 & 100,0 \\
\hline
\end{tabular}

tidak hanya dihadiri oleh anggota yang bekerja yaitu golongan yang berpendapatan rendah dengan berwirausaha namun pendidikan terakhir pun menjadi penghasilan $\geq \mathrm{Rp} 1.500 .000$ yang dipengaruhi tujuan anggota mengikuti pendampingan.

Anggota yang mengikuti pendampingan dengan pendidikan terakhir tamat SD yaitu sebanyak $75 \%$. Hal ini terlihat bahwa anggota Posdaya memiliki tingkat pendidikan yang rendah sehingga menjadi motivasi dalam mengikuti pendampingan. Hasil kesimpulan dapat terlihat bahwa intensitas dalam mengikuti pendampingan dapat berpengaruh terhadap jenis pekerjaan serta tingkat pendidikan. Kegiatan pendampingan lebih diikuti oleh anggota yang bekerja berwirausaha dengan pendidikan terakhir tamat SD.

\section{Tingkat Pendapatan}

Pendapatan dihasilkan dari warga RW 02 setiap harinya dengan melakukan pekerjaan baik menjadi PNS, Pegawai Swasta maupun berwirausaha. Penelitian ini tingkat pendapatan diukur untuk mengetahui pendapatan warga RW 02 sehingga dapat terlihat peran serta Posdaya Bina Sejahtera untuk meningkatkan pendapatan keluarga sehingga warga RW 02 menjadi sejahtera. Pada penelitian ini dapat terlihat pada Tabel di bawah ini yaitu persentase tingkat pendapatan warga RW 02 yang digolongkan menjadi 2. Pada golongan pertama adalah golongan yang berpendapatan tinggi dengan tingkat penghasilan

$<\mathrm{Rp} 1.500 .000$ sedangkan pada golongan kedua oleh jenis pekerjaan anggota Posdaya serta tingkat pendidikan terakhir anggota Posdaya.

Banyaknya anggota yang bekerja sebagai wirausaha dengan pendapatan tinggi yaitu sebanyak $75 \%$. Hal ini dikarenakan wirausaha yang dijalani adalah usaha kebutuhan sehari-hari yang semua orang menggunakan produk yang dijual. Pendidikan sangat berpengaruh terhadap peningkatan pendapatan. Berdasarkan hasil penelitian ini, banyak anggota yang berpendidikan terakhir tamat SD memiliki pendapatan yang tinggi yaitu sebanyak $75 \%$. Hal ini dikarenakan keterbatasan pendidikan yang menjadi motivasi untuk meningkatkan pendapatan sehingga walaupun tamat SD tidak menjadi penghalang untuk menjadi keluarga yang berkualitas.

Tingkat pendapatan yang diperoleh warga dipengaruhi dengan jenis pekerjaan serta tingkat pendidikan. Peran serta Posdaya sangat dibutuhkan untuk meningkatkan Pendapatankeluarga. Pendapatan keluarga akan berpengaruh terhadap kesejahteraan keluarga. Apabila pendapatan rendah maka akan mengakibatkan pendidikan yang kurang untuk anak dan kesehatan yang kurang karena tidak memikirkan kandungan gizi dengan makan yang seadanya. Namun dengan mengikuti kegiatan Posdaya Bina Sejahtera akan membantu dalam meningkatkan pendidikan anak, kesehatan yang tetap terjaga serta ekonomi yang meningkat dengan melalui berwirausaha.Tingkat Tabel 4 Jumlah dan Persentase Responden Berdasarkan Tingkat Pekerjaan Berpengaruh pada Kegiatan Pendampingan, Posdaya Bina Sejahtera, Kelurahan Pasir Mulya, 2013

\begin{tabular}{lccccccc}
\hline \multirow{2}{*}{ Pendampingan } & \multicolumn{4}{c}{ Pekerjaan } & & \multicolumn{2}{c}{ Total } \\
& & Wirausaha & \multicolumn{2}{c}{ Non Wirausaha } & & \multicolumn{2}{c}{} \\
& & Jumlah & Persentase & Jumlah & Persentase & Jumlah & Persentase \\
\hline & Tinggi & 21 & 75,0 & 2 & 100,0 & 23 & 76,7 \\
& Rendah & 7 & 25,0 & 0 & 0,0 & 7 & 23,3 \\
\hline Total & 28 & 100,0 & 2 & 100,0 & 30 & 100,0 \\
\hline
\end{tabular}


Tabel 5 Jumlah dan Persentase Responden Berdasarkan Tingkat Pekerjaan Berpengaruh pada Kegiatan Pendampingan, Posdaya Bina Sejahtera, Kelurahan Pasir Mulya, 2013

\begin{tabular}{lccccccc}
\hline \multirow{2}{*}{ Pendampingan } & & \multicolumn{4}{c}{ Pendidikan } & \multicolumn{2}{c}{ Total } \\
& & SD & \multicolumn{4}{c}{ SMP } \\
& & Jumlah & Persentase & Jumlah & Persentase & Jumlah & Persentase \\
\hline & Tinggi & 21 & 75,0 & 2 & 100,0 & 23 & 76,7 \\
& Rendah & 7 & 25,0 & 0 & 0,0 & 7 & 23,2 \\
\hline Total & & 28 & 100,0 & 2 & 100,0 & 30 & 100,0 \\
\hline
\end{tabular}

pekerjaan serta tingkat pendidikan memiliki pengaruh dalam mengembangkan kewirausahaan baik melalui kegiatan pelatihan, kegiatan pendampingan maupun dalam meningkatkan pendapatan bagi rumah tangga. Jenis kelamin dan golongan umur pada karakteristik anggota Posdaya tidak memiliki pengaruh. Hal ini dikarenakan mayoritas jenis kelamin baik perempuan maupun laki-laki memiliki kemampuan yang sama dalam mengembangkan kewirausahaan. Golongan umurtidakmemilikipengaruh dalammengembangkan kewirausahaan karena umur tidak menjadi penentu dalam mengembangkan kewirausahaan.

\section{Tingkat Pengetahuan}

Pengetahuan merupakan informasi yang dimiliki seseorang untuk melaksanakan tugas dan tanggung jawabnya sesuai bidang yang digelutinya. Pengetahuan merupakan fase awal dimana seseorang bertindak sesuai dengan pengetahuan yang dimiliki. Dalam penelitian ini pengetahuan diukur berdasarkan pengetahuan yang diperoleh anggota dalam kegiatan Posdaya Bina Sejahtera. Pengetahuan tersebut lalu dapat diaplikasikan dalam mengembangkan dirinya ataupun untuk mengembangkan usaha yang digeluti. Pengetahuan tersebut pun dapat diaplikasikan dalam membuat inovasi baru.

Pelatihan dan pendampingan menghasilkan tingkat pengetahuan yang tinggi dengan memiliki persentase sebanyak $83,3 \%$. Hal ini terlihat dari rasa keingintahuan warga dalam kegiatan Posdaya Bina Sejahtera sangat tinggi dalam mengikuti kegiatan baik pelatihan maupun pendampingan. Terdapat anggota yang sering mengikuti pelatihan serta pendampingan namun tingkat pengetahuannya sedang yautu memiliki persentase $75 \%$ untuk anggota yang mengikuti pelatihan, sedangkan $68,7 \%$ untuk anggota yang mengikuti pendampingan. Pengetahuan itu dirasakan oleh warga RW 02 sangat bermanfaat baik mengembangkan kewirausahaan. Banyak warga RW 02 yang mengaplikasikan pengetahuan yang diberikan terutama dalam membuat inovasi baru dan hasilnya dapat dirasakan oleh keluarga yaitu dapat menambah pendapatan keluarga.

Sebagai contoh, Bapak Heri pada awalnya tidak bisa membuat sepatu dan sandal namun dengan adanya pelatihan dan pendampingan dalam membuat sepatu dan sandal dan Bapak Heri mendapatkan pengetahuan tentang membuat sepatu dan sandal sehingga mengaplikasikannya untuk mencoba berwirausaha membuat sepatu dan sandal.Peningkatan pendapatan pula berpengaruh dalam pengetahuan yang diperoleh dalam kegiatan pelatihan dan pendampingan. Berdasarkan hasil tabel diatas dapat terlihat tingkat pengetahuan dapat berpengaruh dalam meningkatkan pendapatan keluarga. Hal ini terlihat banyaknya anggota yang memiliki pendapatan yang tinggi dengan tingkat pengetahuan yang tinggi yaitu sebesar $83,3 \%$.Pada

Tabel 6 Jumlah dan Persentase Berdasarkan Tingkat Pekerjaan Berpengaruh pada Peningkatan Pendapatan, Posdaya Bina Sejahtera, Kelurahan Pasir Mulya, 2013

\begin{tabular}{lcccccrrr}
\hline \multirow{2}{*}{ Pendapatan } & \multicolumn{2}{c}{ Wirausaha } & \multicolumn{2}{c}{ Pekerjaan } & \multicolumn{2}{c}{ Total } \\
& \multicolumn{2}{c}{ Jumlah } & Persentase & Jumlah & Persentase & Jumlah & \multicolumn{2}{c}{ Persentase } \\
\hline & Rendah & 7 & 25,0 & 0 & 0,0 & 7 & 23,3 \\
& Tinggi & 21 & 75,0 & 2 & 100,0 & 23 & 76,7 \\
\hline Total & & 28 & 100,0 & 2 & 100,0 & 30 & 100,0 \\
\hline
\end{tabular}


Tabel 7 Jumlah dan Persentase Berdasarkan Tingkat Pendidikan Berpengaruh pada Peningkatan Pendapatan, Posdaya Bina Sejahtera, Kelurahan Pasir Mulya, 2013

\begin{tabular}{clrr}
\hline No & Akses terhadap Manfaat Kesejahteraan & Jumlah & Persentase \\
\hline 1 & Rendah & 3 & 6,0 \\
2 & Sedang & 4 & 8,0 \\
3 & Tinggi & 43 & 86,0 \\
\hline Total & & 50 & 100,0 \\
\hline
\end{tabular}

pendapatan yang rendah pun memiliki tingkat pengetahuan yang tinggi sebesar $16,7 \%$.

Kesimpulannya tingkat pengetahuan yang diperoleh berpengaruh dalam mengikuti kegiatan baik pelatihan maupun pendampingan. Selain itu, tingkat pengetahuan pula dapat mempengaruhi pendapatan sehingga pengetahuan yang diperoleh dalam mengembangkan kewirausahaan sangat bermanfaat bagi anggota Posdaya Bina Sejahtera.

\section{Tingkat Keterampilan}

Keterampilan dapat dirancang sebagai suatu proses komunikasi belajar untuk mengubah perilaku seseorang menjadi cekat, cepat, dan tepat dalam melakukan sesuatu. Keterampilan ini akan mengali inovasi yang dapat memiliki nilai jual yang tinggi sehingga dapat meningkatkan pendapatan keluarga.

Hasil penelitian menyatakan bahwa tingkat keterampilan dalam mengembangkan kewirausahaan baik dalam membuat inovasi maupun dalam kegiatan pemasarannya. Pada Tabel dibawah ini merupakan jumlah dan persentase tingkat keterampilan warga RW 02 yang diperoleh berdasarkan atas kegiatan pelatihan, pendampingan serta dalam meningkatkan pendapatan. Berdasarkan tabel diatas dapat terlihat tingkat keterampilan warga RW 02 tinggi baik dalam mengikuti pelatihan maupun pendampingan yaitu sebanyak 50\%. Hal ini terlihat banyaknya inovasi yang dilakukan oleh anggota Posdaya untuk meningkatkan kualitas berwirausaha. Tingkat keterampilan yang kurangdisebabkan dengan kurangnya kepercayaan diri dalam menggali inovasi sehingga untuk menciptakan sesuatu takut tidak memiliki nilai jual yang tinggi.

Keterampilan yang dimiliki akan membantu dalam meningkatkan pendapatan. Berdasarkan hasil tabel diatas dapat terlihat peningkatan pendapatan yang tinggi dengan keterampilan yang tinggi yaitu sebesar 70\%. Hal ini disebabkan karena keterampilan yang diperoleh tergantung anggota Posdaya untuk

Tabel 8 Jumlah dan Persentase Tingkat Pengetahuan Responden yang Berpengaruh terhadap Pelatihan, Pendampingan Serta Pendapatan, Posdaya Bina Sejahtera, Kelurahan Pasir Mulya, 2013

\begin{tabular}{|c|c|c|c|c|}
\hline \multirow[t]{2}{*}{ Item } & \multicolumn{4}{|c|}{ Pengetahuan } \\
\hline & Sedang & \multicolumn{3}{|c|}{ Tinggi } \\
\hline Pelatihan & Jumlah & Persentase & Jumlah & Persentase \\
\hline Sering & 9 & 75,0 & 15 & 83,3 \\
\hline Tidak sering & 3 & 25,0 & 3 & 16,7 \\
\hline Total & 12 & 100,0 & 18 & 100,0 \\
\hline \multicolumn{5}{|l|}{ Pendampingan } \\
\hline Tinggi & 8 & 68,7 & 15 & 83,3 \\
\hline Rendah & 4 & 33,3 & 3 & 16,7 \\
\hline Total & 12 & 100,0 & 18 & 100,0 \\
\hline \multicolumn{5}{|l|}{ Pendapatan } \\
\hline Rendah & 4 & 33,3 & 3 & 16,7 \\
\hline Tinggi & 8 & 66,7 & 15 & 83,3 \\
\hline Total & 12 & 100,0 & 18 & 100,0 \\
\hline
\end{tabular}


Tabel 9 Jumlah dan Persentase Tingkat Keterampilan Responden berdasarkan Kegiatan Pelatihan, Pendampingan serta Pendapatan, Posdaya Bina sejahtera, Kelurahan Pasir Mulya, 2013

\begin{tabular}{|c|c|c|c|c|}
\hline \multirow{3}{*}{$\begin{array}{c}\text { Item } \\
\text { Pelatihan }\end{array}$} & \multicolumn{4}{|c|}{ Keterampilan } \\
\hline & \multicolumn{3}{|c|}{ Tinggi } & \multirow{2}{*}{$\begin{array}{l}\text { Rendah } \\
\text { Persentase }\end{array}$} \\
\hline & Jumlah & Persentase & Jumlah & \\
\hline Sering & 19 & 95,0 & 5 & 50,0 \\
\hline Tidak sering & 1 & 5,0 & 5 & 50,0 \\
\hline Total & 20 & 100,0 & 10 & 100,0 \\
\hline \multicolumn{5}{|l|}{ Pendampingan } \\
\hline Tinggi & 18 & 90,0 & 5 & 50,0 \\
\hline Rendah & 2 & 10,0 & 5 & 50,0 \\
\hline Total & 20 & 100,0 & 10 & 100,0 \\
\hline \multicolumn{5}{|l|}{ Pendapatan } \\
\hline Rendah & 6 & 30,0 & 1 & 10,0 \\
\hline Tinggi & 14 & 70,0 & 9 & 90,0 \\
\hline Total & 20 & 100,0 & 10 & 100,0 \\
\hline
\end{tabular}

mengaplikasikan dalam kehidupan sehari-hari sehingga dapat merubah pendapatan keluarga. Namun terdapat peningkatan pendapatan dengan rendahnya keterampilan yaitu sebanyak 90\%. Hal ini dikarenakan usaha yang dijalankan banyak dibutuhkan orang lain sehingga apabila tidak dapat menciptakan inovasi namun usaha yang dijalankan tetap maju.

\section{Sikap}

Sikap merupakan pola tingkah laku seseorang di dalam melaksanakan tugas dan tanggung jawabnya sesuai dengan peraturan. Penerapan sikap ini merupakan pola perilaku yang menggambarkan jati dirinya. Sikap tersebut dapat mencerminkan kedewasaan seseorang dalam berfikir. Apabila seseorang yang memiliki tingkat kedewasaan yang rendah maka pola berfikir serta bersikap yang buruk namun sebaliknya apabila pola berfikir dan bersikap yang baik akanmematangkan kedewasaan seseorang.

Penelitian ini dimaksudkan sikap yang menggambarkan diri menjadi karakteristik kewirausahaan. Pola fikir yang positif sangat dibutuhkan dalam mengembangkan kewirausahaan. Berikut ini adalah Tabel ini yang merupakan jumlah dan persentase dalam mengukur sikap yang menggambarkan pribadi lebih menunjang dalam mengambangkan kewirausahaan melalui kegiatan pelatihan, pendampingan maupun dalammeningkatkan pendapatan. yang dapat menunjang dalam mengembangkan kewirausahaan sangat tinggi yang lebih terlihatdari kegiatan pelatihan dan pendampingan. Hal ini terlihat dari persentase yang yang dihasilkan sebanyak $76 \%$. Hal ini dibuktikan dengan sikap mereka dalam mengembangkan kewirausahaan yaitu tetap berwirausaha walaupun banyak tantangan yang dihadapi terutama dalam bersaing. Persaingan dalam berwirausaha menjadi pembelajaran untuk mengembangkan kewirausahaan untuk lebih berkembang.

Pola berfikir berpengaruh terhadap pendapatan. Hal ini terlihat diatas yaitu pada sikap yang tinggi memiliki pendapatan yang tinggiyaitu sebesar $61,5 \%$ dan $88,2 \%$ untuk sikap yang sedang. Pada kesimpulannya sikap sebagai pola fikir anggota Posdaya berpengaruh terhadap pelatihan dan pendampingan serta peningkatn pendapatan.

\section{Kesimpulan}

Kesimpulan dalam penelitian ini ialah (1) Karakteristik anggota lebih banyak anggota yang berjenis kelamin perempuan dengan golongan umur produktif akhir serta bekerja berwirausaha dengan pendidikan terakhir SD yang menunjang dalam mengembangkan kewirausahaan dan (2) Kompetensi yang diperoleh dalam mengembangkan kewirausahaan lebih dominan diperoleh yaitu pada 
pengetahuan serta sikap.

\section{Daftar Pustaka}

Aisyah.2006. Hubungan Antara Karakteristik Individu dan Sikap Terhadap Iklan di Televisi dengan Perilaku Ibu Rumah Tangga dalam Menggunakan Produk Detergen.[Skripsi]. Bogor (ID). Bogor (ID): Fakultas Ekologi Manusia, Institut Pertanian Bogor.

Buchari A. 2003. Kewirausahaan. Bandung(ID): Alfabeta.

Azwar S. 2003. Sikap Manusia Teori dan Pengukurannya. Yogyakarta(ID): Pustaka Pelajar.

Azzahra R. 2009. Perilaku Wirausaha mahasiswa Institut Pertanian Bogor Peserta Program Kreativitas Mahasiswa Kewirausahaan (PKMK) dan Program Pengembangan Kewirausahaan Mahasiswa (PPKM) [skripsi]. Bogor (ID): Fakultas Ekonomi dan Manajemen, Institut Pertanian Bogor.

Badan Pusat Statistik.2013.Angka Kemiskinan Indonesia. [Internet].18.40 [Diunduh 2013 September 5 ].http://www.detik.com

Gunawan W.1999.Persepsi dan Perilaku Sosial Ekonomi Masyarakat Desa Sirnasari Terhadap Pelestarian Sumberdaya Hutan di Taman Nasional Gunung Halimun. [skripsi]. Bogor(ID): IPB.

Harihanto. 2001. Persepsi, Sikap, dan Perilaku Masyarakat terhadap Air Sungai:

Kasus Program Kali Bersih di Kaligareng, Jawa Tengah [Tesis]. Bogor (ID): Program Pascasarjana, Institut Pertanian Bogor.

Hutapea P, Thoha N.2008. Kompetensi Plus. Jakarta(ID): PT Gramedia Pusaka Utama.

Karmawidjaya T. 2007.360 Derajat HR Management Audit.Jakarta(ID): PT Gemaku Nusaku Persada.

Kasmir. 2006. Kewirausahaan. Jakarta(ID): PT. Raja Grafindo Persada.

Kelurahan Pasir Mulya. 2008. Monografi Pendidikan Masyarakat Kelurahan Pasir Mulya.

Nenny A. 1995. Perbandingan Sikap Kewirausahaan di Antara Pengusaha Industri Kecil Berhasil, Statis dan Tidak Berhasil.[Tesis].Universitas Indonesia: Jakarta (ID).

Notoatmojo S. 1993. Ilmu Kesehatan Masyarakat. Jakarta(ID): Rineka Cipta.

Palan R. 2007. Competency Management. Jakarta(ID):
Penerbit PPM.

Posdaya Bina Sejahtera. 2007. Selayang Panjang Posdaya Bina Sejahtera.

Pudji M. 2011. 100 Pengenalan Posdaya. Bogor ID: IPB Press.

Ramanti RP. 2006. Perilaku Wirausaha Wanita Peternak dalam Mencari dan Menerapkan Informasi Usahaternak Ayam Buras (Kasus Kelompok Tani-ternak "Tanjung”, Desa Taman Sari, Kecamatan Taman Sari, Kabupaten Bogor) [skripsi]. Bogor. Fakultas Peternakan, Institut Pertanian Bogor.

Rukun Warga 02 Pasir Mulya. 2008. Data Jumlah Penduduk serta Pendidikan Warga RW 02.

Ruky SA. 2003. SDM Berkualitas.Jakarta (ID):PT Gramedia Pustaka Utama.

Sarwono SW. 2002. Psikologi Sosial Individu dan Teori Psikologi Sosial.JakartaID: Balai Pustaka. Sears DO, Freedman JL, Peplau LA. 2004. Psikologi Sosial.Jakarta(ID): Erlangga.

Suyono H, Haryanto R. 2009. Buku Pedoman Pembentukan dan Pengembangan Pos Pemberdayaan Keluarga. Jakarta(ID): PT Balai Pustaka.

Singarimbun M, Effendi S. 1989. Metode Penelitian Survai. Jakarta(ID):LP3ES

Soesarsono.2002.Pengantar Kewirausahaan, Bogor (ID): Fakultas Teknologi Pertanian, Institut Pertanian Bogor.

Sutanto A. 2002. Kewirausahaan. Jakarta(ID): Ghalia Indonesia.

Tawardi B. 1999. Sikap Kewirausahaan Anggota Kelompok Belajar Usaha dan Beberapa Faktor yang Mempengaruhinya [Tesis]. Bogor (ID): Sekolah Pascasarjana IPB.

United Nations Development Program. 2008. Human Development Reports. [Internet].19.00 [Diunduh 2013 Juni 29].

Widodo W.2005.Jendela Cakrawala Kewirausahaan. Bogor(ID):IPB Press.

Winardi J. 2003. Entrepreneur dan Entrepreneurship. Jakarta(ID):Prenada Media. 